\title{
GROUP ACTIONS TO PROMOTE ADOLESCENTS' HEALTH
}

\author{
Etiene Oliveira Silva de Macedo', Maria Inês Gandolfo Conceição²
}

\begin{abstract}
The study analyzed Brazilian articles on research in basic health units, which used educative activities as methodology, in order to ascertain the main characteristics of those activities being conducted in primary health care services. The following units were accessed: Lilacs, Scielo and Adolec. The articles were categorized according to these criteria: (1) articles published in Brazilian journals about (2) group interventions with adolescents for health promotion (3) in basic health units, (4) between 2000-2010. The texts were analyzed according to the following items: professionals involved, methodological features, topics covered in the groups, frequency, number of participants, age, sex, the conception of adolescence present in the studies as well as results presented by the authors. The results showed a larger number of actions based on epidemiological and biomedical research. The services described in these publications for focused on group interventions the prevention of risk behavior in sexual and reproductive health rather than considering the diversity of factors related to the adolescents' overall health concerns.
\end{abstract}

Key words: adolescence; groups; health promotion.

\section{INTRODUCTION}

Adolescence is widely accepted as a transitional period of life between childhood and adulthood, which is characterized by physical and psychological changes that are defined in a specific age group. To the World Health Organization (WHO), adolescence is the period between 10 and 19 years old, featured by biological, psychological and social changes, whose common thread is puberty ${ }^{1}$. The prevalent interpretation in the healthcare area is that these changes generate in adolescents the need to produce behaviors that make them vulnerable, especially in issues related to sexuality and psychoactive substance use.

Although the puberty is considered the starting point to the process of adolescence, it is important to highlight that being an adolescent varies according to cultures and eras. This term has often been understood as a period of radical transformations, which casts the adolescents in relationships out of their families and is marked by an idea of an intense crisis. Authors such as Erikson,
Aberastury and Knobel were used by the healthcare area to support our reflections on adolescence ${ }^{2,3}$.

Such theories brought great contributions to the understanding of the adolescence, but it is important to recognize the special contribution of the psychosocial perspective based on the idea of crisis. This perspective suggests the existence of a process of identity reorganization that occurs in order to experience the following stage of the life cycle, in which bio-psycho-social changes are also expected. In this study, we emphasized the implications on the healthcare arena when the notion of crisis is adopted in the biomedical perspective only.

From this perspective, the crisis states something out of the linear or ordinary course, as a condition or cause of a clinical picture. An aspect that deserves consideration is that the idea of crisis suggests, to the social imaginary, the representation of adolescents as being naturally problematic.

However, depending on the socio-cultural environment, it is difficult to determine what is supposed to be normal and pathological. Hence,

1 Graduate Program in Clinical Psychology and Culture - University of Brasília

2 Graduate Program in Clinical Psychology and Culture - University of Brasília Fellow Senior CAPES

Corresponding author: etienemacedo@gmail.com

Suggested citation: Macedo EOS, Conceição MIG. Group actions to promote adolescents' health; Journal of Human Growth and Development 2013; 23(2): 222-230

Manuscript submitted Aug 01 2012, accepted for publication Dec 192012. 
whatever the theoretical framework adopted, it is necessary to adopt a critical posture and an ethical commitment to the diversity of subjective experiences, aiming at the understanding of these individuals in their entirety ${ }^{4}$.

The literature shows that the confusion in defining the terms puberty and adolescence has brought consequences for the activities and programs focused on adolescents ${ }^{4,5}$. Although these terms refer to psychological and physiological processes, they are culturally defined and should not be considered as natural processes. Adolescents from different backgrounds should experience this period differently, so we better to talk in the plural: puberties and adolescences.

Recognizing the diversity of experiences, life conditions, and ethnic, economic and cultural characteristics, among others, the Ministry of Health has also adopted the expression adolescences and youths, in order to understand this multiplicity of factors, in a continuum, implying differentiated experiences with a subjectivity that is particularized in the experience of each individual ${ }^{6}$. Within this perspective, besides extirpating the ills that affect this population, the Ministry of Health suggests that the actions should consider three dimensions: the macro social dimension, related to issues of social class, inequalities, gender and ethnicity; the institutional dimension, which relates to the teaching devices, the productive and market relations and also the biographical dimension, that is the personal trajectory of the adolescent. Yet, there is much to reflect on withe regard to the institutional devices.

In developing actions for these individuals, it is necessary to question the stigmatized images that cross the concept of adolescence. Understanding adolescence based on socially unfavorable models is a misguided approach, as it reaffirms a stereotyped picture of what being an adolescent means ${ }^{7}$. Although there is a multiplicity of froints of vins, there is a consensus that adolescence is a distinct moment in the process of human development between childhood and adulthood. However, cultural, environmental, social and economic factors determine the ways one experiences adolescence and they go beyond the limits established by age rating ${ }^{8,5}$.

Although there are some guidelines of the Ministry of Health regarding the comprehensive healthcare of adolescents and youths, few articles have described systematized models of service addressed to this population. These programs are still applied in isolated contexts and do not undergo a continuous process of evaluation, making it difficult to extende and disseminatedthen an a larger scale ${ }^{9}$.

Group interventions have been identified in these publications as being a powerful vehicle for communication and promotion of behavioral changes. Such group interventions have also been used because they lead to the emergence of individual issues in a collective context, in which the encounter with the other makes discussions and reflections the current conflicts possibles and mades to on democratic solutions ${ }^{10}, 11,12,13$. Health promotion is another important concept for this study. It relates to a set of actions and behaviors aiming at the improvement of the population's living condition. Such actions are aimed at general welfare, extrapolating the notion of solving the problem of diseases. Health promotion requires coordination between the State and society, through the development of policies can be applied and can also reach people in their diverse contexts ${ }^{14,15}$.

The World Health Organization (WHO) defines as initiatives in health promotion programs that are designed based on the following principles: holistic approach, inter-sectoriality, empowerment, social participation, equality, multi-strategy actions and sustainability. Thus, both the empowerment and social participation are conceived as key principles and highlighted as goals of health promotion ${ }^{16}$.

This study intends to discuss the undertaking of educational activities aimed at the promotion of adolescents' health by the group approach, which is an activity considered to be important in this field. The proposal is to think of health promotion in close interdependence with the psychosocial and environmental factors, understanding that a permanent reflection regarding these conceptual positions encourage, in practice, adolescents to participate in different types of expression, selfdiscovery and the possibility of hinging out their own abilities, strengths and limitations ${ }^{8}$.

The objective of this literature review is to identify Brazilian articles on research understaken in basic health units, which used educational activities as methodology, in order to ascertain the main characteristics of the activities being conducted in primary health care services.

\section{METHODS}

A literature review has been understaken in order to identify the research done in basic health units in Brazil that focused on the promotion of adolescents' health and which have used group intervention as this methodology.

The articles found were indexed in the following databases: LILACS (Latin American and Caribbean Literature of Information in Health Science), SCIELO (Scientific Electronic Library Online) and ADOLEC (Project of the Pan American Health Organization concerning publications on adolescence). The inclusion criteria were: (1) articles published in Brazilian journals (2) group interventions with adolescents for health promotion (3) in units of basic healthcare, (4) between 20002010.

The keywords used were: group(s), intervention, adolescent(s), health, basic care, SUS (Unified Health System), workshop(s), in various 
Boolean combinations, located in the abstracts of the articles. Theses, dissertations, and technical publications were excluded from this study. The article has been based on the definition of adolescence given by the World Health Organization (WHO)whide regards it as the period commencing at the age of 10 . What is more, the term preadolescent was taken intra consideration when identified in the search.

First of all, we read all the titles and abstracts of the available articles. From these readings, we built up a table to analyze each article that addressed enable us the performance of groups in health care services.

This table was coded into nine criteria: professionals involved, methodological characteristics, themes addressed in the groups, frequency, number of participants, age, sex, the conception of adolescence in the studies and the results presented by the authors. These criteria were elaborated from the readings and analyses of the abstracts of the
45 articles found in the first step of the review, and are synthesized in Table 1.

The information analyzed was put into an encoded standard file developed by the authors by the use of the Excel application. The organization of the articles enabled us to make numeric and nonnumeric analyses of the information, which was the basis for the results presented.

\section{RESULTS}

Of the, 45 articles found in the first phase of the research, 33 were excluded: one of the articles referred to a group held in a shelter, 14 articles to groups held in the community or in community centers or other living spaces, 13 groups were held in schools and 5 of the studies did not mention the context in which the interventions were undertaken. Only 12 articles referred to research or interventions carried out at basic healthcare units, or at primary healthcare units. These articles were analyzed according to the criteria set out in Table 1.

Table 1: Details of the articles found in databases Lilacs, Scielo, and Adolec according to following criteria: professionals involved, methodological characteristics, themes addressed in the groups, frequency, number, age and sex of participants, concepts of adolescence and results

\begin{tabular}{ll}
\multicolumn{1}{c}{ Analysis Criteria } & \multicolumn{1}{c}{ Details } \\
Professionals involved & $\begin{array}{l}\text { Specific area of practice, Multi-disciplinary professional team, } \\
\text { volunteers }\end{array}$ \\
$\begin{array}{l}\text { Methodological Characteristics } \\
\text { Themes addressed in the groups }\end{array}$ & $\begin{array}{l}\text { Theortical approach, definition of operational strategy } \\
\text { included in the guidelines of Ministry of Health for the attention to } \\
\text { adolescent health. }\end{array}$ \\
Frequency & $\begin{array}{l}\text { Weekly, monthly group, single meeting } \\
\text { Number of participants } \\
\text { Age of participants }\end{array}$ \\
$\begin{array}{l}\text { Sex } \\
\text { Conception of adolescence }\end{array}$ & $\begin{array}{l}\text { Male or female } \\
\text { Theories on which the authors based their description of }\end{array}$ \\
Results & $\begin{array}{l}\text { adolescence } \\
\text { Results described in the articles }\end{array}$
\end{tabular}

Among all the groups held at units of primary healthcare (12 articles), 7 were reported by nursing professionals and 5 were reported by psychology professionals. Curiously, the other areas of knowledge that had published research on adolescents (Medicine and Dentistry) did not report studies in these locations, but their participation was of direct insertion in the community. These later were not analyzed because they refer to activities in different spaces from basic health units.

Regarding the methodological characteristics of these groups, the prevalence of the participatory approach on health education (25\%) was observed, addressed by nursing professionals. Then, there were the discussion groups oriented by by the reflective critical pedagogy of Paulo Freire (17\%) and the group discussions grounded on the social representations theory $(17 \%)$, also coordinated by nursing professionals. The therapeutic groups with psychoanalytical orientation (17\%) were described by psychologists, followed by a group that was oriented by a cognitive behavioral theory (16\%) and a historical-cultural theory ( $8 \%$ ) (Figure 1 ).

These methodological choices were guided by underlying theoretical assumptions. Health education, which is defined as a basic action in which interactions among people who take part in it can undertake or assist in the improvement of their health conditions ${ }^{20}$, was widely used in the nursing clinic. The instruments used in these groups were reflections on the reports of situations and experiences lived, dramatizations, photo language and discussions ${ }^{20,21,22}$.

The focus group was another strategy used both for data collection related to the topics discussed in the groups and to the development of strategies for health education. In these groups, the convergence research-care-education as perceived in the performing of the actions. The objective of it was the integration of the knowledge 


\section{Methodological characteristics identified in the articles}

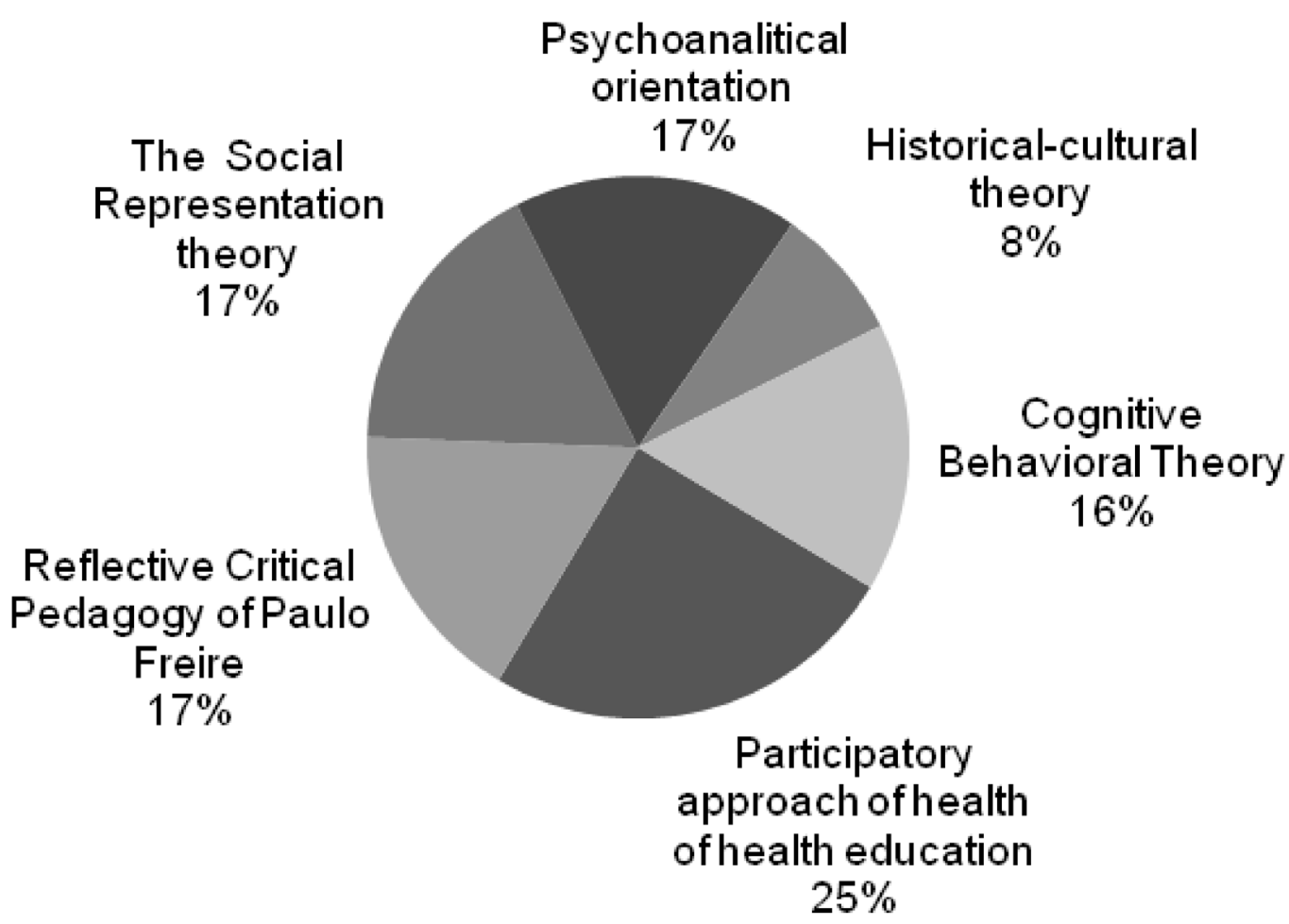

Figure 1: Distribution of articles percentage according to their methodological characteristics: Participatory approach of Health Education, Reflective Critical Pedagogy of Paulo Freire, The Social Representation Theory, Psychoanalytical orientation, Historical-cultural Theory, and Cognitive Behavioral Theory.

of the universe researched with effective actions aimed at mobilizing the adolescents to their actively in the search for solutions to the problems they face in everyday life.

In general, groups performing with adolescents was cited as an important space for identity formation and experiencing new roles, different from those experienced in the family. Participatory methodologies were valued as allowing reflection and the discussion of the issues raised. The themes and contents addressed were: sexuality and sexually transmitted diseases (42\%), sexual abuse $(8 \%)$, use of alcohol and psycho-active substances $(8 \%)$, Oedipus complex $(8 \%)$, life skills $(8 \%)$, identity, health and life project $(8 \%)$.

The frequency of these groups was not described in $50 \%$ of the reports. On the other hand, it is known that $25 \%$ of them were hold weekly and the other $25 \%$ were single sessions. Regarding duration, six of these groups described it ranging from 60 to 90 minutes, three of them did not report the length of the meetings, two lasted more than 90 minutes and only one group lasted less than 60 minutes.

The numbers of participants varied from 4 to 10 and from 11 to 20 people each in $25 \%$ of the groups; $33 \%$ did not mention the number of participants and $8 \%$ of the groups were carried out with over 20 participants or were groups open to any number of participants. In half of the studies $(50 \%)$, the age of the participants was not described. In the other half of the studies, the group participants were between 10 and 14 years old $(25 \%), 14$ to 18 years old ( $17 \%)$ and 12 to 19 years old $(8 \%)$. In $58 \%$ of the groups, the adolescents were of both sexes, $25 \%$ of the studies did not mention the gender of the participants and $17 \%$ were specific groups for girls. Tables 2, 3 and 4 show the results regarding the frequency of the groups, the numbers and age of the participants.

Table 2: Number and percentage of frequency of the groups serving adolescents: weekly, single session, not reported and total

$\begin{array}{lc}\begin{array}{l}\text { Frequency of the groups serving adolescents } \\ \text { reported in the articles }\end{array} & \text { N } \\ & 3 \\ \text { Weekly } & 3 \\ \text { Single meeting } & 6 \\ \text { Not reported } & \mathbf{1 2} \\ \text { Total } & \end{array}$


Table 3: Number and percentage of participants: Not reported, four to 10,11 to 20 , more than 20 and total

Number of participants reported in the articles

Table 4: Number and percentage of participants' age group: 10 to 14,14 to 18,12 to 19 years old, and total

$\begin{array}{lr}\text { Age of the participants of the studies } \\ \\ \text { N } \\ 10 \text { to } 14 \text { years } & 3 \\ 14 \text { to } 18 \text { years } & 2 \\ 12 \text { to } 19 \text { years } & 1 \\ \text { Not reported } & 6 \\ \text { Total } & \mathbf{1 2}\end{array}$

Regarding the conception of adolescence an which the studies analyzed were based, a search was undertaken for the explanation of this concept in the introductionsw to the article and also in the results and references used by the authors. In $42 \%$ of the articles (three studies) this information was not explicit. The prevalence of the biomedical approach (25\%, three studies) and psychoanalytic approach ( $25 \%$, three studies) was identified to describe characteristics of this phase. The culturalhistorical approach appeared next in $8 \%$ of the reports (one study).

The biomedical approach, based on the concept adopted by the World Health Organization (WHO), emphasizes the maturational aspects of puberty and addresses the adolescents as vulnerable to risk behaviors. Moreover, epidemiological research was widely cited in these studies to guarantee the relevance of the educational work with groups of adolescents.

The articles based on the psychoanalytic approach to adolescence valued the psychodynamic process of adolescence as a constituent phase of identity and also of the process of individualization and separation from the parental figures, and also to other forms of socialization. Classical authors (Freud, Arminda Aberastury, Winnicott, Melaine Klein, among others) were widely quoted in these articles in preference to contemporary authors who have discussed the relationship between adolescence and culture more deeply.

These results corroborate the trend already observed by Peres and Rosemburg ${ }^{5}$ (1998): the emphasis on biological and individual aspects of the adolescent tend to regard the process of adolescence as universal when, in fact, the categories adolescence and adolescent should be distinct. This means that even though the term adolescence is designed according to preestablished parameters, lived facts particularize the uniqueness of the teenager as someone who suffers, thinks, feels, produces and reproduces in his daily life.

The cultural-historical approach developed by Vygotsky was also identified in one of the researched articles and it supported the development of workshops an sexuality with adolescents. Writhim a perspective that addressed the naturalization of sexuality of adolescents and its problems critically, the authors articulated the notion of sexual responsibility and emancipation of the individual in the field of sexual reproductive rights ${ }^{4}$.

The World Health Organization (WHO) suggests carrying out actions aimed at developing life skills in working with adolescents. This is a theoretical-methodological option that has grown in Brazil, with specific adaptations for working with adolescents ${ }^{12,13}$. Specific actions in basic health units were not found in the articles analyzed.

Regarding the results presented in the articles, the authors described experiences of group therapy based on psychodynamic approaches, as well as reflection and focus groups. The former did not have as their objective a evaluat ion of the outcomes of group psychotherapy, but focused on the understanding of psychodynamic aspects related to the topics studied ${ }^{24}$.

Another theoretical model identified in the analysis of the results was the Theory of Social Representations, a psycho-sociological approach that has been used in both social and health sciences to understand the beliefs, values and attitudes of people in relation to health care. This approach represents a breakthrough in the planning of health education actions for adolescents, in the sense that when the beliefs, values and attitudes regarding the adolescents' own health are considered, the strategies developed can effectively meet their needs and demands ${ }^{20,21}$.

The results presented reaffirmed how important the actions in the groups with adolescents were so that they perceived the necessity of transforming their reality and behaviors so as to start practicing healthier habits and positive attitudes. However, the results presented did not report the development of specific evaluative processes to measure whether these results would be achieved or not over time. The account of the adolescents' verbalization about the importance of participating in the groups showed us that it is necessary to implement long-term programs that undergo evaluations in all their stages.

The evaluations that were reported seemed to occur more often from the points of view of the facilitators or coordinators of the groups, who recorded their impressions and reviews about the development of the activities. This corroborates the 
literature reviewed as it points to the lack of research in the area and also to the lack of more effective programs with well-defined intermediate and final goals being both systematically evaluated $^{9,18}$.

The articles also discussed the evaluation of participatory methodology has not been carried out, the authors emphasized both the group relationship and the role of the facilitator as fundamental for the adolescents' membership of and participation in the groups. The bond and trust between the facilitator and the other participants were essential for the success of the actions.

The need to involve schools and other community organizations in training activities was also discussed, since these adolescents are sent for treatment in basic health units by those institutions. The studies analyzed found that isolated approaches have little impact in the representation of adolescents concerning their behavior, so such approaches do not guarantee changes ${ }^{18,21}$.

\section{DISCUSSION}

There was little research, taking group intervention as a methodology with adolescents at basic healthcare units, in the period 2000-2010. It was concentrated mainly from the year 2006 on cards with $72 \%$ of the publications found.

This is a considerable number of people when we recall that the laws and policies addressed to adolescents were created just two decades ago. According to the literature reviewed, full attention was given to adolescents' healthcare as from the 1990 s and it has been growing ever since, but it is little systematized with specific and vertically actions $^{9,4,17-19}$.

The Unified Health System (hereby SUS) is a useful field in which to conduct educational activities aimed at leadership and empowerment of the population, as also actions of health promotion ${ }^{31}$. In the case of the adolescent, the small number of Brazilian publications in the last decade relates to the invisibility of the population despite advances in legislation and public policies ${ }^{30}$.

As we realized, the advance in actions and programs aimed at youth needs to adopt a different attitude to the social and collective dimension that surrounds the daily life of adolescents. The approach to adolescence exclusively by the biomedical paradigm means that health promotion practices to healing practices of a current illness or the prevention of more serious complaints ${ }^{31}$.

This review showed the prevalence of educational activities which seek to inform and guide adolescents with regard to sexuality, pregnancy and prevention of sexually transmissible diseases (the DST/AIDS). These themes appeared as prioritized areas for intervention with this age group.

In order to achieve effective action of this kind it is essential to offer conditions that enable the adolescents to make choices coherent with their reality. We cannot entire autonomy and behavioral change just by giving information and orientation about techniques to prevent DST/AIDS and unwanted pregnancy. Thus, whatever the knowledge we offer to the adolescents, we also need to take their daily life into consideration and prevent not just information, but also room to discuss what they consider as a relevant issues ${ }^{29,30}$.

According to the Ministry of Health, group activities have primacy in this age group because of the therapeutic character assumed by the group, which becomes an ideal place to promote health ${ }^{6}$. In this sense, professionals who work promote health are faced with the challenge of using creative methodologies that encourage social participation, more than fulfilling the normative principles. Such principles imply the need for the users to submit to the regulatory proposal, with no regard for their daily and private experiences.

It is important to reflect on the historical and contextual nature of the development of the adolescent category. Whem the subjective perspective of these individuals is not taken into account, the group approach to adolescents functioning as a means of holding them can head to the failure of the policies offered ${ }^{14}$.

In the articles analyzed, the action trends have prevailed so as to collaborate with the pathological perspective even when these actions were reportedly educational. Such a perspective comes into play to characterize adolescence exclusively as a period of crisis or by giving prominence to the biological aspects of the changes that occur during this period.

It is important to state that these changes are seen as structuring psychological and social transformations. In order to overcome the tradition of generalizing adolescence without considering the specific features of the individuals involved, it would be necessary to be part of one of the guiding principles of the programs and policies aimed at adolescents' health.

In developing actions addressed to such individuals it is necessary to consider the stigmatized images that are part of the concept of adolescence. Plus, adolescents require a special look that particularizes their subjectivity while extending it to the situational aspect. However, what we commonly find in the theoretical-practical thinking of the actions and programs is the perspective of a crisis in itself that is initiated in puberty and has a delimited end. This transience ends up by silencing the individual to whom the interventions are directed. Having stated that, the adolescent himself ends up in a non-place whether we consider the action performed withim the institutional context or in the public policy offered $^{25,26}$.

For this reazon, what should be prioritized is the dialogue between scientific and popular knowledge whenever we seek for solutions to the 
challenges encontered. It is this kind of relationship that enables the professionals to adopt a new approach to the adolescents' health. Such posture differs from the concept of health in education, which is based on the imposition of technical knowledge that is merely aimed at changing behaviors that are considered harmful to health. This posture also implies gotting to know the needs reported by the community itself ${ }^{27,28}$. In other words, professionals and users should discuss and create together the solutions to the each unique situation by promoting the development of skills that are useful in the various contexts of everyday life.

The prevention programs addressed to adolescents' risk behaviors have not achieved good results especially in the area of sexuality and sexually transmitted diseases seeing that the objective is to promote behavioral changes ${ }^{18}$. What is stated above is relates to a complex process characterized by affective, cognitive and ideological elements and thast takes place on the short and long term. Hence, it is necessary that the current actions and programs should include the evaluation of the processes and goals by having well-defined intermediate and final goals.

It is possible to conclude from the small number of articles identified that the publications partially express the initiatives aimed at promoting adolescents' health. Certainly, there are successful initiatives, but in documented, which shows how profitable a closer relationship between professional and academic practices would be, so that the actions undertaken in these spaces are included and mentioned in specific bibliographies. It is necessary to systematize the actions taken and disseminate them more widely in the scientific field so that the reflection on the categories adolescence and health promotion with should become widely known.

The groups reported in the publications appeared to be isolated initiatives since they were not connected to programs focuseing on adolescent health. These actions would gain greater visibility if they were included in the programs referred to and also if they were placed on the research agenda of the professionals and researchers engaged in the field.

\section{REFERENCES}

1. World Health Organization. Adolescent Health, 2011.[acesso em 24 jul 2011] Available at < h t t p : / / w w w. who.int/topics / adolescent_health/en/>.

2. Erikson E. Identidade, juventude e crise. Rio de Janeiro: Jorge Zahar, 1976; p.128-136, 322p.

3. Aberastury A, Knobel M. Adolescência normal. $10^{a}$ edição. Porto Alegre: Artes Médicas; 1992; p.24-59, 92p.
Forthier, in those publications the prevalence of the concept of the adolescent crisis and it reflects the misguided appropriation of the term and its impact on health actions. Although these articles used participatory methodologies, the interventions were aimed at informing, guiding and educating the individuals so that they could make their own changes to improve their health. It is not intended in this study to assert whether there is an adolescent crisis or not, but rather to reflect on the fact that if this idea is wrougly interpreted it leads to unsuccessful practices. Having considered that incorrect interpretation, such practices may seek to cure or remedy it, while the actions should engage in providing care and support for the adolescents rather than to try to eradicate the evils attributed to adolescence.

Considering the limited amount of research reported in the literature on group actions to promote adolescent it is hoped that health, this study will serve as a starting point for reflection on the importance of empowering professionals who work in health units to develop and strengthen initiatives for health promotion ${ }^{30}$.

This literature review showed the need to prepare the professional for the promotion of health in a positive outlook upon teens, which should value more their own resources and quality of life. If the actions continue to prioritize themes like violence, sexuality and drug use, there is a risk to reiterate the naturalized view about the adolescents as being irresponsible and immature.

Finally, what should be prioritized are actions that take into account the specifics of this process in order to meet specific demands without generalizing adolescence as an equal process for all adolescents. Moreover, it is important to promote the participation of adolescents in the planning and decision making processes related to health promotion strategies.

\section{ACKNOWLEDGEMENTS}

Special thanks are due to the National Council for Scientific and Technological Development (CNPQ) and the Coordination for the Improvement of Higher Level Personnel (CAPES) for their financial support.

4. Maheirie K, Urnau LC, Vavassori MB, Orlandi R, Baierle RE. Oficinas sobre sexualidade com adolescentes: um relato de experiência. Psicol. estud.[periódico online]. 2005 [acesso em 23 nov 2010]; 10(3):537-42. Disponível em: <http://www.scielo.br/scielo.php?script =sci_arttext\&pid=S141373722005000300022\& Ing=en\&nrm=iso >. ISSN 1413-7372. http://dx.doi.org/10.1590/S141373722005000300022

5. Peres F, Rosenburg CP. Desvelando a concepção de adolescência/adolescente presente no 
discurso da saúde pública. SaudeSoc, [periódico online]. 1998 [acesso em 23 nov 2010]; 7(1): 53-86. Disponível em: <http://www.scielo.br/ scielo.php?script $=$ sci_arttext $\&$ pid $=$ S0104$12901998000100004 \&$ Ing $=$ en $\& n r m=$ iso $>$.ISSN 0104-1290. http://dx.doi.org/10.1590/S010412901998000100004

6. Brasil. Ministério da Saúde. Secretaria de Atenção em Saúde. Departamento de Ações Programáticas Estratégicas. Diretrizes nacionais para atenção integral à saúde de adolescentes e jovens, na promoção, proteção e recuperação da saúde. Brasília: Ministério da Saúde, 2010; p.43-49, 132p.

7. Tonelli MJF. Direitos sexuais e reprodutivos: algumas considerações para se pensar o lugar da psicologia e sua produção teórica sobre a adolescência. Psicol, Soc., [periódico online]. 2004 [acesso em 23 nov 2010]; 16(1): 15160. Disponível em<http://www.scielo.br/ scielo.php?script $=$ sci_arttext $\&$ pid $=$ S0102$71822004000100013 \& \mathrm{lng}=\mathrm{pt \& nrm}=\mathrm{iso}>$. ISSN 1807-0310. http://dx.doi.org/10.1590/ S0102-71822004000100013

8. Traverso-Yépez MA, Pinheiro VS. Adolescência, saúde e contexto social: esclarecendo práticas. Psicol. Soc, [periódico online]. 2002, [acesso em 23 nov 2010]; 14(2): 133-47. Disponível em: $\quad<$ http://www.scielo.br/ scielo.php?script $=$ sci_arttext\&pid=S0102$71822002000200007 \& \operatorname{lng}=$ en\&nrm $=$ iso $>$.ISSN 1807-0310. http://dx.doi.org/10.1590/S010271822002000200007

9. Murta SG. Programas de prevenção a problemas emocionais e comportamentais em crianças e adolescentes: lições de três décadas de pesquisa. Psicol. Reflex. Crit., [periódico online]. 2007; [acesso em 23 nov 2010]; 20(1): 1-8. Disponível em<http://www.scielo.br/ scielo.php? script $=$ sci_arttext\&pid=S0102$79722007000100002 \&$ Ing $=p t \& n r m=i s o>$.ISSN 0102-7972. http://dx.doi.org/10.1590/S010279722007000100002

10. Santos KL, Quintanilha BC, Dalbello-Araújo M. A atuação do psicólogo na promoção de saúde. Psicol. teor.prat, [periódico online]. 2010; [acesso em 23 nov 2010]; 12(1): 181-96. Disponível em:<http://pepsic.bvsalud.org/ scielo.php?script $=$ sci_arttext\&pid $=$ S1516$36872010000100015 \&$ Ing $=p t \& n r m=i s o>$. ISSN 1516-3687.

11. Oliveira CB, Frechiane JM, Silva FM, Maciel ELN. As ações de educação em saúde para crianças e adolescentes nas unidades básicas da região de Maruípe no município de Vitória. Ciênc., saúde coletiva, [periódico online]. 2009; [acesso em 23 nov 2010]; 14(2): 635-44. Disponível em: <http://www.scielo.br/ scielo.php? script $=$ sci_arttext\&pid $=$ S1413$81232009000200032 \&$ Ing $=p t \& n r m=i s o>$. ISSN 1413-8123. http://dx.doi.org/10.1590/ S1413-81232009000200032
12. Silva MP, Murta SG. Treinamento de habilidades sociais para adolescentes: uma experiência no programa de atenção integral à família (PAIF). Psicol. Reflex. Crit., [periódico online]. 2009; [acesso em 23 nov 2010] ; 22(1): 136-43. Disponível em : <http://www.scielo.br/ scielo.php?script $=$ sci_arttext\&pid=S0102$79722009000100018 \&$ Ing $=$ pt\&nrm $=$ iso $>$.ISSN 0102-7972. http://dx.doi.org/10.1590/S010279722009000100018

13. Déa, HRFD, Santos, EN, Itakura, E, Olic TB. A inserção do psicólogo no trabalho de prevenção ao abuso de álcool e outras drogas. Psicol. cienc. prof.,[periódico online]. 2004 [acesso em 23 nov 2010]; 24(1): 108-115. Disponível em : <http: //pepsic.bvsalud.org/ scielo.php?script $=$ sci_arttext $\&$ pid $=S 1414$ $98932004000100012 \& \mathrm{lng}=\mathrm{pt \& nrm}=i$ so $>$. ISSN 1414-9893.

14. Andrade EA, Bógus CM. Políticas públicas dirigidas à juventude e promoção da saúde: como a proposta de auxiliares da juventude foi traduzida em prática. Interface - Comunic., Saude, Educ., [periódico online]. 2010; [acesso em 23 nov 2010]; 14(35): 853-66. Disponível em: http://www.scielo.br/scielo.php? script $=$ sci_arttext\&pid=S1414 $32832010000400011 \& \mathrm{lng}=$ en\&nrm=isoEpub Oct 01, 2010. ISSN 1414-3283. http://dx.doi.org/ 10.1590/S1414-32832010005000033

15. Santos KF, Bógus CM. A percepção de educadores sobre a escola promotora de saúde: um estudo de caso. Rev. Bras. Crescimento Desenvolv. Hum., [periodic online]. 2007; [acesso em 23 nov 2010]; 17(3): 123-33. Disponível em: <http://pepsic.bvsalud.org/ scielo.php?script $=$ sci_arttext\&pid $=$ S0104$12822007000300013 \& \mathrm{lng}=$ pt\&nrm $=i s o>$. ISSN 0104-1282.

16. Sícoli J, Nascimento PR. Promoção de saúde: concepções, princípios e operacionalização. Interface - Comunic., Saude, Educ., [periódico online]. 2003; [acesso em 23 nov 2010]; 7(12):101-22. Disponível em: <http:// w w w. scielo.br/scielo.ph p ? script $=$ sci_arttext\&pid=S 1414 $32832003000100008 \& \mathrm{lng}=\mathrm{en} \& \mathrm{nrm}=$ iso $>$.ISSN 1414-3283. http://dx.doi.org/10.1590/S141432832003000100008

17. Faustini DMT, Novo NF, Cury MCFS, Juliano Y. Programa de orientação desenvolvido com adolescentes em centro de saúde: conhecimentos adquiridos sobre os temas abordados por uma equipe multidisciplinar. Ciênc., saúde coletiva, [periódico online]. 2003; [acesso em 23 nov 2010]; 8(3): 783-90. Disponível em: <http://www.scielo.br/ scielo.php?script $=$ sci_arttext $\&$ pid $=$ S1413$81232003000300012 \& \mathrm{lng}=$ en $\& n r m=$ iso $>$.ISSN 1413-8123. http://dx.doi.org/10.1590/S141381232003000300012 
18. Jeolás LS, Ferrari RAP. Oficinas de prevenção em um serviço de saúde para adolescentes: espaço de reflexão e conhecimento compartilhado. Ciênc., saúde coletiva, [periódico online]. 2003; [acesso em 23 nov 2010]; 8(2): 611-20. Disponível em: <http:// www.scielo.br/scielo.php?script = s c i - art text \& p i d = S 1413 $81232003000200021 \& \mathrm{lng}=$ en $\& \mathrm{nrm}=$ iso $>$. ISSN 1413-8123. http://dx.doi.org/10.1590/ S1413-81232003000200021

19. Silva LAV, Oliveira RF, Franco ALS. Inserção do psicólogo em programas de atenção primária à adolescência: uma experiência em SalvadorBahia. Psicol. Reflex. Crit., [periódico online]. 1998; [acesso em 23 nov 2010]; 11(3): 60520. Disponível: <http://www.scielo.br/ scielo.php?script $=$ sci_arttext\&pid $=$ S0102$79721998000300017 \& \mathrm{lng}=\mathrm{en} \& \mathrm{nrm}=\mathrm{iso}>$.ISSN 0102-7972. http://dx.doi.org/10.1590/S010279721998000300017

20. Ferreira MA. A educação em saúde na adolescência: grupos de discussão como estratégia de pesquisa e cuidado-educação. Texto contexto - enferm., [periódico online]. 2006; [acesso em 23 nov 2010]; 15(2): 20511. Disponível em: <http://www.scielo.br/ scielo.php?script $=$ sci $\_$arttext\&pid=S0104$07072006000200003 \&$ lng $=$ en $\&$ nrm $=$ iso $>$.ISSN 0104-0707. http://dx.doi.org/10.1590/S010407072006000200003

21. Souza SL, Ferriane MGC, Silva MAI, Gomes R, Souza TC. A representação do consumo de bebidas alcoólicas para adolescentes atendidos em uma Unidade de Saúde da Família. Ciênc., saúde coletiva, [periódico online]. 2010; [acesso em 23 nov 2010]; 15(3): 733-41. Disponível em: <http://www.scielo.br/ scielo.php? script $=$ sci_arttext\&pid $=$ S1413$81232010000300016 \&$ Ing $=$ en $\& n r m=$ iso $>$.ISSN 1413-8123. http://dx.doi.org/10.1590/S141381232010000300016

22. Souza MM, Borges IK, Medeiros M, Teles SA, Munari DB. Programa educativo sobre sexualidade e DST: relato de experiência com grupo de adolescentes. Rev. bras. enferm., [periódico online]. 2006; [acesso em 23 nov 2010]; 60(16): 102-5. Disponível em: <http:/ /www.scielo.br/scielo.php?script= s c i a r t t e x t \& p i d = S 0034 $71672007000100020 \&$ Ing $=$ en $\&$ nrm $=$ iso $>$.ISSN 0034-7167. http://dx.doi.org/10.1590/S003471672007000100020

23. Murta SG. Programa de habilidades de vida para adolescentes: manual para aplicação. Goiânia: Porã Cultural, 2008; p.9-13, 80p.
24. Bodstein K, Arruda SLS. Fantasias sexuais e edípicas em pré-adolescentes atendidos em grupo de psicoterapia lúdica. Arq. Bras. Psicol.,[periódico online]. 2006 [acesso em 23 nov 2010]; 58(1): 58-74. Disponível em: < h t t p : / / pepsic.bvsalud.org / scielo.php?script $=$ sci_arttext $\&$ pid $=$ S1809$52672006000100007 \& \mathrm{lng}=\mathrm{pt \& nrm}=$ iso $>$. ISSN 1809-5267.

25. Fonseca DC, Ozella S. As concepções de adolescência construídas por profissionais da Estratégia de Saúde da Família (ESF). Interface - Comunic., Saude, Educ., [periódico online]. 2010; [acesso em 23 nov 2010]; 14(33): 41124. Disponível em: <http://www.scielo.br/ scielo.php?script $=$ sci_arttext\&pid $=$ S1414$32832010000200014 \&$ Ing $=$ en $\&$ nrm $=$ iso $>$.ISSN 1414-3283. http://dx.doi.org/10.1590/S141432832010000200014.

26. Abramo HW. Considerações sobre a tematização social da juventude no Brasil. Rev. Bras. Educ. Número especial: juventude e contemporaneidade. 1997; 5-6: 25-36.

27. Ruzany $\mathbf{M H}$. Atenção à saúde do adolescente: mudança de paradigma. em: Brasil. Ministério da Saúde. Secretaria de Atenção à Saúde. Departamento de Ações Programáticas Estratégicas (Org.).Saúde do adolescente: competências e habilidades Brasília: Editora do Ministério da Saúde, 2008, p.21-5.

28. Dimenstein M. Los (des)caminos de la formación profesional del psicólogo en Brasil para la actuación en la salud publica. Rev Panam Salud Publica, [periódico online]. 2003; [acesso em 23 nov 2010]; 13(5): 341-45. Disponível em: <http://www.scielosp.org/scielo.php? script $=$ sci_arttext\&pid = S 1020 $49892003000400014 \&$ Ing $=e n \& n r m=i s o>$.ISSN 1020-4989. http://dx.doi.org/10.1590/S102049892003000400014.

29. Mendonça GMM, Abreu LDP, Silva MAM, Andrade MP. Promoção da saúde sexual de puérperas adolescentes: conhecimento e práticas. Adolescência e Saúde [periódico online].2012; [acesso em 06 fev 2013]; 9(2): 14-20. Disponível em http://www.adolescencia esaude.com/resumo.asp?id=311. ISSN 21775281.

30. Macedo EOS. Significações sobre adolescência e promoção entre os participantes de um grupo educativo [dissertação]. Brasília: Programa de Pós-Graduação em Psicologia Clínica e Cultura, Universidade de Brasília; 2012.

31. Santos AAG, Silva RM, Machado MFAS, Vieira LJES, Catrib AMF, Jorge HMF. Sentidos atribuídos por profissionais à promoção da saúde do adolescente. Ciência \& Saúde Coletiva, 2012. 17(5); 1275-84. 